\title{
Стерняева А.А. \\ Формирование министерской системы управления в первой половине 19 века
}

Ульяновский государственный университет (Россия, Ульяновск)

doi:10.18411/spc-20-11-2017-14

idsp: 000001:spc-20-11-2017-14

\section{Аннотация}

Именно в этот период победоносно завершилась Отечественная война 1812 года и Европа в очередной раз убедилась в непререкаемом авторитете России на внешней арене, подтверждаемом военной силой и народной поддержкой. Утратила свою актуальность либеральная идея, не нашедшая поддержку у народа (1825 г.), значительно расширилась территория России, окончательно сформировалось ее геополитическое значение как центра притяжения соседствующих с ней территориальных образований. В этот период к России присоединилась Грузия (1801 г.), Азербайджан и Армения (1829 г.). Важнейшим событием середины XIX столетия стала Крымская война (1853 - 1856 гг.), в результате которой Россия одержала крупнейшую дипломатическую победу - город Севастополь был признан европейским сообществом территорией России.

Ключевые слова: министерская система, учреждение министерств, манифест, единоначалие, разделение дел

\section{Abstract}

It was during this period triumphantly ended the Patriotic war of 1812 and Europe once again became convinced of the unquestioned authority of Russia in the international arena, supported by military force and popular support. Lost its relevance, the liberal idea has not found support of the people (1825), greatly expanded the territory of Russia, and finally formed its geopolitical significance as the centre of gravity of its neighboring territorial units. During this period, has joined Russia and Georgia (1801), Azerbaijan and Armenia (1829). The most important event of the mid-NINETEENTH century was the Crimean war (1853 1856), in which Russia won a major diplomatic victory for the city of Sevastopol was recognized by the European community to the territory of Russia.

Keywords: Ministerial system, the establishment of ministries, Manifesto, unity of command, division of Affairs

В этот период отмена крепостного права (1861 г.) явилась важнейшим этапом экономического развития России и ее индустриализации, крестьянская реформа ознаменовала смену феодального способа производства капиталистическим. В свою очередь судебная реформа 1864 года способствовала развитию судоустройства, процессуального и отчасти материального права Российской империи, смогла в значительной степени нейтрализовать произвол бюрократии, реально обеспечить права и неприкосновенность личности.

Все эти события свидетельствуют о принципиальном сходстве современных политических реалий и ситуации, сложившейся в России с начала века и до 1864 года, при том, что данная ситуация, безусловно, требовала усиленной нормотворческой деятельности всего государственного аппарата.

Таким образом, анализ исторического пути нормотворчества как организационно-правовой формы деятельности в сфере управления важен с точки зрения определения места, которое оно занимает в процессе развития государства и права, а также с учетом того, что именно нормотворчество следует считать ведущим 
механизмом обеспечения реформ в сфере государственного управления, политики, экономики и т. д.

Исторический путь нормотворческой деятельности в России в указанный период, а также ее сложный, нередко противоречивый характер требуют осмысления с точки зрения эффективности, исторической целесообразности, а также организационного совершенства.

С приходом к власти императора Александра I (1777 - 1825 гг.) было провозглашено, что в основе его политических устремлений всегда будет лежать строгое соблюдение законов, а его видение сущности законодательной деятельности свидетельствует о прогрессивном взгляде монарха на проблемы нормотворчества. Александр I считал, что «закон должен быть для всех единствен, и по общей его силе ... ясным и разбору не подлежащим». Император задавался вопросом: «Как скоро я себе дозволю нарушить законы, кто тогда почтет за обязанность наблюдать их? Быть выше их, если бы я и мог, но конечно бы не захотел, ибо я не признаю на земле справедливой власти, которая бы не от закона истекала; напротив, я чувствую себя обязанным первее всех наблюдать за исполнением его, и даже в тех случаях, где другие могут быть снисходительны, а я могу быть только право-судным».

При этом следует указать на тот факт, что нормотворческая деятельность самого императора была весьма продуктивной, за почти 25 лет его правления акты, изданные государем, включены в 14 томов «Полного собрания законов Российской империи», в частности тома с 27-го по 39-й полностью посвящены законодательным актам (указам, манифестам) императора, частично законотворческие акты Александра I вошли в 26-й том и 40-й том, всего объем его законотворчества составляет более 10700 актов.

Наиболее важным из всего перечня законодательных актов, изданных Александром I за время его правления, являются высочайшие манифесты и указы, которые касались правового сопровождения реформ государственного управления, начало которым положил Манифест «Об учреждении министерств» от 8 сентября 1802 года и Указ Сенату «Об образовании первых трех коллегий в образе производства государственных дел на прежнем основании и о лицах, избранных к управлению министерствами».

Создание министерств на принципах единоначалия министров было вызвано необходимостью повышения оперативности управленческой системы. Вместе с тем коллегиальный принцип принятия решений имел место в новой системе: сначала коллегии были введены в состав вновь созданных министерств, а впоследствии при министрах функционировали рады, которые приобрели статус коллегиального органа.

В соответствии с Манифестом учреждался состав первых министерств: военных сухопутных сил, военных морских сил, иностранных дел, внутренних дел, финансов, коммерции и народного просвещения и юстиции.

В свою очередь Указом Сената от 8 сентября 1802 г. были назначены министры и их заместители, получившие статус «товарищ министра», также наряду с министрами был назначен государственный казначей. Следует отметить, что министерская реформа мало затронула коллежскую систему управления, существовавшую в России. Фактически речь шла об их переподчинении определенному министерству при фактической неизменности функций и организационного устройства, порядка делопроизводства и т. д.

Непосредственно в министерствах вводился смешанный порядок управления, основные положения которого были включены в Манифест «Об учреждении министерств», и данный порядок может быть обозначен как «министерскоколлежский». Его сущность состоит в том, что каждый нижестоящий орган на основе 
изучения и систематизации текущих дел и проблем управления представлял министру еженедельные отчеты (мемории), на которые министр отвечал своими предложениями.

Отношение министра к законодательной власти закреплялось в ст. 220 Общего учреждения министерств. Здесь четко указывалось, что министрам были предоставлены права законодательной инициативы; участия в рассмотрении законопроектов; объявления словесных Высочайших повелений; а также они обязывались присутствовать на общих собраниях Государственного совета, где участвовали в голосовании наравне с прочими членами. В рамках непосредственно исполнительной власти министерства были связаны с Сенатом и Комитетом министров в случаях, когда их компетенции не хватало для решения возникающих управленческих вопросов. По Общему учреждению министерств циркулярное предписание об исполнении существующего закона всеми ведомствами подлежало изданию через Сенат.

А когда дело «не могло быть разрешено Сенатом» или требовало Высочайшего разрешения, министры должны были обращаться в Комитет министров. Как указывает И.В. Михеева, конкретным министерствам предоставлялись полномочия по созданию подзаконных норм в развитие существующих правил. Так, министерство просвещения имело право издавать распоряжения «в части управления, в случаях, требующих дополнения законов пояснений, их отмены или исправления...».

В целом, по нашему мнению, именно коллегии были той организационной основой, которая способствовала относительно бесконфликтному и быстрому формированию министерской системы управления. $\mathrm{C}$ целью дальнейшего совершенствования министерской системы управления были приняты Манифест «О разделении государственных дел на особые управления, со значением предметов каждому управлению принадлежащих» от 25 июля 1810 г., «Высочайше утвержденное разделение государственных дел по министерствам» от 17 августа 1810 г. и «Общее учреждение министерств» от 25 июня 1811 г.

В Манифесте все государственные дела были структурированы и разделены в соответствии с функциональным признаком на дела о:

1) внешних сношениях;

2) об устройстве внешней безопасности;

3) о государственной экономии;

4) об устройстве гражданского и уголовного суда;

5) об устройстве внутренней безопасности.

Данным нормативно-правовым актом было создано министерство полиции и Главное управление духовных дел разных исповеданий, в систему государственного управления включалась должность ревизора государственных счетов, «государственного контролера», упразднялось министерство коммерции, а его функции переходили в предмет ведения ми-нистерства финансов и министерства внутренних дел.

«Высочайше утвержденное разделение государственных дел по министерствам» от 17 августа 1810 г. определяло структуру ряда министерств, таких как министерство внутренних дел, министерство народного просвещения, министерство финансов. Законодательный акт, получивший название «Общее учреждение министерств» от 25 июня 1811 г. стал главным нормативно-правым актом министерской реформы, который определил систему организации министерств. Совещательный орган при министерстве - совет министра состоял из руководителей основных подразделений и имел значение органа для рассмотрения дел, требующих коллегиального обсуждения. Данный документ определял порядок образования министерств и их функции, приводил к определенному стандарту формы юридических документов. 
Следует отметить, что в соответствии с положениями «Общего учреждения министерств» министрам предоставлялось право и обязанность «разрешать силою существующих законов все затруднения и сомнения, возникающие в администрации при исполнении законов и распоряжений», указывалось, что «предписания министра могут быть двух родов: в одних объявляются именные Высочайшие повеления, в других - министр действует собственною его властию».

В принципе можно считать, что указанные выше законодательные акты в своих основах завершили министерскую реформу, а все сферы государственного управления полу-чили главный орган управления - министерство. Сама же система министерств функционировала на основе принципа разграничения полномочий и меры ответственности, что способствовало централизации управления, построению в России первой «властной вер-тикали», имеющей возможности реализации своих властных полномочий посредством законотворческой деятельности.

Царствование Николая I (1796 - 1855 гг.) прошло под знаком дальнейшей централизации государственного управления, в данный период были созданы условия, необходимые для будущих преобразований, в частности для проведения крестьянской, судебной реформы.

Николай I стремился подчинить всецело себе центральное управление, установил строгий порядок еженедельных «всеподданнейших докладов» министров лично ему. Секретный комитет под председательством В.П. Кочубея, созданный для «пересмотра государственного управления» (6 декабря 1826 г.), имел предписание работать и готовить проекты секретно, силами доверенной бюрократии, не привлекать даже дворянские общественные силы. Задумывались реформы для централизации системы управления, укрепления ее 3 а-конной основы, искоренения произвола чиновников - этого извечного зла российского управления.

Проведены меры по укреплению центрального управления с помощью петровского опыта его милитаризации. Главами большинства министерств назначены генералы: мини-стром духовных дел и народного просвещения назначен адмирал А.С. Шишков, министром государственных имуществ - генерал П.Д. Киселев, оберпрокурором Синода - гусарский полковник Н.А. Протасов. Введено военное устройство в управлении путями со-общения, лесным делом.

Александр II (1818, - 1881 гг.) во второй половине XIX в. в рамках преобразований, вошедших в историю под названием «великие реформы», провел реформу системы государственного управления, доведя ее до высшей степени централизации. В политическом строе России появились новые элементы правового государства, создавались и новые органы, имеющие непосредственное отношение к процессу нормотворчества.

Наиболее заметным новшеством в сфере высших органов власти было создание в 1861 году Совета министров (действовал до 1882 года) в качестве нового совещательного органа под председательством самого императора. В него вошли председатели Комитета министров и Государственного совета, министры и руководители главных управлений. Этот ближайший к императору государственный орган в основном рассматривал вносимые монархом вопросы. Ему же принадлежала инициатива созыва Совета министров.

Совет министров, который возник в процессе подготовки реформ Александра II, был создан Указом 12 ноября 1861 г., получил статус высшего при императоре органа под его председательством для решения вопросов общегосударственного значения. В его состав вошли высокие должностные лица: главноуправляющие, председатели Комитета министров и Госсовета, другие близкие царю официальные лица.Как, например, организационно-правовой основой для 
начала разработки программы реформ стало издание Александром II 20 ноября 1857 г. известного рескрипта (предписания) на имя Ковенского, Виленского и Гродненского генерал-губернатора В. Назимова.

По определению И. Мироновой, рескрипт как акт монарха адресовался или на имя определенного должностного лица, или обществу. В данном случае документ направлялся должностному лицу и стал следствием совещания при участии министра внутренних дел С. Ланского, министра государственного имущества Г. Муравьева с $\mathrm{B}$. Назимовым. Его участники приняли «общие начала» освобождения крестьян, которые и легли в основу императорского рескрипта [6, с. 53]. Указанный документ в историографии небезосновательно называют первой официальной правительственной программой крестьянской реформы.

В упомянутом рескрипте, впоследствии растиражированном и направленном руководителям других губерний, непременно указывалось, что «освобождение крестьян от крепостной зависимости» должно проходить по собственному желанию местного дворянства.

Рассмотрением материалов, подготовленных дворянскими комитетами, и составлением проектов реформ занималось отделение «Редакционные комиссии», созданное 4 февраля 1859 г. Александром II в подчинении Главного комитета по крестьянским делам, созданного на базе бывшего Тайного комитета, для подготовки общего проекта и местных Положений обустройства быта помещичьих крестьян. Среди членов этого отделения, кроме чиновников, были «эксперты» от помещиков.

Руководителем «комиссий» был назначен Я. И. Ростовцев, а после его смерти в феврале 1860 г.- помещик В. М. Панин. Осенью 1860 г. редакционные комиссии подготовили проекты «Положения» о крестьянах, вышедших из крепостной зависимости. 10 октября 1860 г. проекты были переданы в Главный комитет, где они обсуждались и дополнялись до 14 января 1861 г., а потом поступили в Государственный совет, где проходило их об-суждение до 17 февраля. «Дальнейшее ожидание, - заявил Александр II, открывая заседание Госсовета, - может только еще более возбудить страсти и привести к нежелательным последствиям как для всего государства вообще, так и для помещиков в частности. Вы убедились, что все, что можно было сделать для ограждения выгод помещиков, сделано».

Итак, 19 февраля 1861 г. глава государства подписал законопроекты о крестьянской реформе, вошедшие в историю под названием «Положение 19 февраля». В тот же день увидел свет специальный Манифест о ликвидации крепостного права, обнародование которого должно происходить «через чтение во всех православных и католических церквах».

Таким образом, совокупность министерств в Российской империи в рассматриваемый период окончательно обрела статус централизованной системы.

$$
* * *
$$

1. Журналы и мемории Общего собрания Государственного совета по крестьянскому делу (с 28 января по 14 марта 1861 года). - Птг.: Гос. тип. 1915. С. 4.

2. Коротких М.Г.Судебная реформа 1864 года в России (сущность и социально-правовой механизм формирования): Дис... докт. юрид. наук: 12.00.01. Воронеж. 1989. 400 с.

3. Письма и указы императора Александра I. 1801-1803 гг. // Русская старина. 1870. Т. 1. 612 с.

4. Михеева И.В. Российское правотворчество: традиционные акценты истории // Журнал российского права. 2010. № 10. С. 98-104. Режим доступа: http://www.juristlib.ru/book_9875.html Дата обращения: 14.09.2017

5. Миронова И.А.Законодательные памятники пореформенного периода (1861-1900 гг.): учеб. пособ. - М., 1960.-С. 8.

6. Полное собрание законов Российской империи. Собр. 1-е. Т. XXXI. [Электронный ресурс]. Режим доступа: http://www.nlr.ru/e-res/law_r/content.html Дата обращения 01.09.2017 